P-ISSN 2580 - 7781

E-ISSN 2615 - 3238

\title{
RESPON DUA VARIETAS KUBIS (Brassica oleracea L.) DATARAN RENDAH TERHADAP DOSIS PUPUK NPK
}

\section{RESPONSE OF TWO VARIETIES OF CABBAGE (Brassica oleracea L.) LOWLAND TO DOSAGE OF NPK FERTILIZER}

\author{
Rennanti Lunnadiyah Aprilia ${ }^{1)}$, Rahmat Joko Nugroho ${ }^{2)}$ \\ ${ }^{1,2}$ Agroteknologi, Pertanian dan Peternakan, UMNU Kebumen \\ ${ }^{1}$ Email: renantihadeejah@gmail.com
}

\begin{abstract}
ABSTRAK
Budidaya tanaman kubis awalnya hanya ditanam di daerah dataran tinggi. Dalam perkembangannya, kubis mulai banyak ditanam di dataran menengah dan bahkan di dataran rendah. Hal ini seiring dengan ditemukannya varietas - varietas baru yang sesuai untuk daerah dataran rendah. Salah satu upaya yang dapat dilakukan petani kubis dataran rendah agar meningkatkan produktivitas kubis di daerah dataran rendah dengan menggunakan varietas, dosis pemupukan dan perawatan yang tepat. Tujuan dari penelitian ini yaitu untuk mengetahui respon dua varietas Kubis dataran rendah terhadap dosis pupuk di dataran rendah. Penelitian dilakukan di lahan milik petani daerah Kabupaten Kebumen. Penelitian dilaksanakan dengan menggunakan RAK dengan dua faktor yaitu Varietas dan dosis pupuk. Data hasil pengamatan yang diperoleh dianalisis dengan analisis sidik ragam (ANOVA) dan diuji lanjut dengan metode LSD pada $\alpha=5 \%$ untuk mengetahui perbedaan antar perlakuan yang diuji. Hasil penelitian menunjukkan V2 yaitu Grand 22 mempunyai adaptasi yang lebih baik di daerah Surotrunan Kebumen. Pupuk rekomendasi P3 yaitu (150 kg/ha Urea,200 kg/ha SP36, $150 \mathrm{~kg} / \mathrm{ha} \mathrm{KCL).} \mathrm{Masih}$ memungkinkan dilakukan penelitian lanjutan dengan dosis yang lebih tinggi.
\end{abstract}

Kata kunci: Varietas kubis, Dataran rendah, Dosis pupuk

\begin{abstract}
Initially, cabbage cultivation was only planted in upland areas. In its development, cabbage is widely planted in the middle plains and even in the lowlands. This is in line with the discovery of new varieties suitable for lowland areas. One of the efforts that lowland cabbage farmers can do is to increase the productivity of cabbage in lowland areas by using the right variety, fertilizer dosage and care. The purpose of this study was to determine the response of two lowland varieties of cabbage To fertilizer doses in the lowlands. The research was conducted on land owned by farmers in the area of Kebumen Regency. The research was carried out using RAK with two factors, namely variety and fertilizer dosage. The data obtained from the observations were analyzed by means of analysis of variance (ANOVA) and further tested by the LSD method at $\alpha=5 \%$ to determine the differences between the treatments tested. The results showed that V2, namely Grand 22, has a better adaptation in the Surotrunan Kebumen area. The

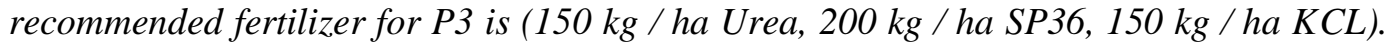
It is still possible to carry out further research at a higher dose.
\end{abstract}

Keywords: Cabbage varieties, Lowland, Dosage of fertilizer. 
P-ISSN 2580 - 7781

E-ISSN 2615 - 3238

\section{PENDAHULUAN}

Kubis merupakan tanaman hortikultura yang dapat di tanam di daerah yang berhawa sejuk di dataran tinggi antara 800-1000 m dpl dan bertipe iklim basah, namun ada juga varietas kubis yang dapat ditanam di dataran rendah sekitar 0-200 m dpl. Pada dataran rendah kubis merupakan salah satu tanaman sayuran yang memiliki potensi besar untuk dikembangkan, karena peluang pasar yang terbuka lebar. Menurut catatan BPS, rata-rata ekspor kubis Indonesia per tahun dalam kurun waktu 2013 -2017 mencapai 4.500 ton per tahun. Pada periode Januari Agustus 2018 mencapai 24,6 ribu ton, naik dari periode yang sama tahun 2017 sebanyak 22,1 ribu ton. Kubis sebagai komoditas sayuran yang paling banyak diekspor dibanding jenis sayuran lain seperti jagung manis, bawang merah, selada dan sebagainya. Produksi kubis rata-rata per tahun selama 5 tahun terakhir mencapai 1.463.126 ton. Pada tahun 2017 lalu mencapai 1.442.624 ton setahun dan menjadikan Indonesia sebagai salah satu produsen terbesar di dunia (Prihasto, 2018)

Tanaman kubis dapat tumbuh maksimal pada tanah yang subur, gembur, porous dan banyak mengandung humus. $\mathrm{pH}$ ideal untuk tanaman kubis antara 6 hingga 7. Hal tersebut sesuai dengan daerah Surotrunan Alian. Namun demikian pengembangan kubis di dataran rendah khususnya di daerah Surotrunan Kecamatan Alian Kabupaten Kebumen harus dikaji terlebih dahulu varietas dan berapa dosis pupuk yang paling tepat untuk menghasilkan pertumbuhan dan hasil optimal. Pemupukan pada dasarnya adalah usaha untuk mencukupi kebutuhan tanaman akan hara agar berbagai proses fisiologis tanaman dapat berjalan dengan baik. Uraian tersebut menunjukkan permasalahan varietas yang tepat di dataran rendah Desa Surotrunan. Selain itu perlu dikaji dosis pupuk dasar yang paling tepat jika dibandingkan dengan rekomendasi yang ada berdasarkan penelitian sebelumnya untuk mendapatkan hasil yang optimal. Tujuan dari penelitian ini yaitu untuk mengetahui respon dua varietas Kubis dataran terhadap dosis pupuk. 
P-ISSN 2580 - 7781

E-ISSN $2615-3238$

\section{METODE PENELITIAN}

Penelitian dilakukan di lahan milik petani Desa Surotrunan, Kecamatan Alian, Kabupaten Kebumen. Bahan yang digunakan adalah kubis varietas hibrida dan bukan hibrida. Penelitian dilaksanakan dengan menggunakan Rancangan Acak Kelompok dengan dua factor yaitu V1= Varietas Hibrida; V2=bukan varietas hibrida dan macam dosis pupuk dasar. Macam dosis pupuk dasar yang digunakan yaitu P0 = control (tanpa diberi pupuk dasar), P2 = pupuk dasar dengan dosis rekomendasi (100 kg/ha Urea, 150kg/ha SP36, $100 \mathrm{~kg} / \mathrm{ha} Z \mathrm{ZA}, 150 \mathrm{~kg} / \mathrm{ha}$ KCL). P1= (50 kg/ha Urea, $75 \mathrm{~kg} / \mathrm{ha} \mathrm{SP36,} 50 \mathrm{~kg} / \mathrm{ha} \mathrm{ZA,} 75 \mathrm{~kg} / \mathrm{ha} \mathrm{KCL}) . \mathrm{P} 3=$ (150 kg/ha Urea, $200 \mathrm{~kg} / \mathrm{ha} \mathrm{SP} 36,150 \mathrm{~kg} / \mathrm{ha} \mathrm{KCL})$. Kemudian diberi pupuk susulan dengan dosis yang sama pada 20 HST dan 30 HST. Alat yang digunakan adalah Cangkul, timbangan kasar, alat tugal, rol meter, timbangan digital, jangka sorong, papan naman, gunting dan alat tulis. Data hasil pengamatan diperoleh dari pengamatan data kemudian data yang diperoleh dianalisis dengan analisis sidik ragam (ANOVA) dan diuji lanjut dengan metode LSD pada ambang taraf kesalahan sebesar 5\% untuk mengetahui perbedaan antar perlakuan yang diuji.

\section{HASIL PENELITIAN DAN PEMBAHASAN}

Parameter yang diamati pada hasil pertumbuhan tanaman kubis terdiri atas tinggi tanaman, jumlah daun, umur membentuk krop, dan luas daun. Sedangkan untuk variabel hasil tanaman, yang diamati adalah panjang akar, berat segar tanaman, berat segar krop, diameter krop, diameter batang.

Hasil analisis dari pertumbuhan tanaman kubis dapat dilihat pada tabel dibawah.

Tabel 1. Hasil Analisis Ragam Komponen Pertumbuhan Tanaman

\begin{tabular}{llccc}
\hline NO & Variabel & Varietas & Dosis Pupuk & $\begin{array}{c}\text { Interaksi Varietas } \\
\text { dan dosis } \\
\text { pupuk/kelompok }\end{array}$ \\
\hline 1 & Tinggi tanaman & th & tn & $*$ \\
2 & Jumlah daun & tn & tn & tn \\
3 & Luas daun & $*$ & tn & tn \\
\hline
\end{tabular}

1. Tinggi tanaman

Tinggi tanaman merupakan variabel penting dalam pengamatan untuk mengetahui pertumbuhan tanaman. Tinggi tanaman dapat menjadi indikator 
P-ISSN $2580-7781$

E-ISSN 2615 - 3238

apakah tanaman dapat menerima unsur hara yang diberikan. Berdasarkan penelitian minggu ke- 8 merupakan fase dimana tanaman kubis memiliki tingkat pertumbuhan yang pesat dalam membentuk organ-organ tanaman. Selain itu pada minggu ke-8 sampai minggu ke-12 dimana tanaman kubis mulai muncul crop dan waktu pembentukanya dengan adanya pembentukan crop menunjukan adanya perubahan tinggi tanaman yang cenderung rendah, hal ini dikarenakan pada minggu-minggu tersebut tanaman kubis mulai membentuk krop daun sehingga cadangan makanan atau nutrisi pada pupuk lebih digunakan untuk pembentukan krop pada tanaman kubis.

Berdasarkan Tabel Annova diatas menunjukkan tinggi tanaman berbeda nyata pada faktor varietas. Pada uji BNT $\alpha 5 \%$, Terlihat bahwa varietas Grand 22 mempunyai kemampuan untuk menyerap unsur hara dengan baik terbukti rata-rata tinggi tanaman lebih baik jika dibanding dengan varietas Sehati. varietas Grand 22 masih memungkinkan untuk dilakukan penelitian lanjutan agar mengetahui dosis maksimal yang bisa digunakan agar pertumbuhan tanaman menjadi lebih optimal. Menurut Waugh et al. (1973) untuk mendapatkan data awal rekomendasi pemupukan dapat dilakukan jalan pintas melalui pendekatan multi nutrient response. Percobaan dilakukan dengan cara menanam pada tiga percobaan paralel perlakuan pemupukan N, P, dan K. Masing-masing pupuk menggunakan dosis bertingkat, sehingga didapat kebutuhan masing-masing hara pada kondisi threshold yield (ambang batas) dan juga kondisi maksimum. Threshold yield mengacu pada titik awal respon hasil akibat tanpa pemberian tambahan hara. Pendekatan multi nutrient response akan menghasilkan empat pilihan rekomendasi, yaitu berdasarkan pemupukan maksimum serta ambang batas pemakaian pupuk N, P, dan K. Penelitian ini bertujuan untuk menentukan dosis optimum pemupukan $\mathrm{N}, \mathrm{P}$, dan $\mathrm{K}$ agar pertumbuhan dan produksi tanaman kubis maksimum sebagai upaya untuk mendapatkan data awal rekomendasi pemupukan. Pendekatan multi nutrient response digunakan sebagai metode untuk menentukan rekomendasi tersebut. 
P-ISSN 2580 - 7781

E-ISSN $2615-3238$

\section{Jumlah daun dan luas daun}

Daun merupakan unsur atau organ tanaman yang paling penting. Karena di daun tanaman dapat memperoleh makanan hasil fotosintesis. Tanaman dalam pertumbuhannya memerlukan unsur hara untuk pembentukan organ-organ tanaman salah satunya pembentukan daun. Dalam pertumbuhannya tanaman akan menyerap unsur hara yang tersedia dalam tanah atau media tanam yang akan dibawa ke daun untuk dilakukan fotosistesis yang kemudian hasil dari fotosintesis tersebut akan digunakan untuk pertumbuhan tanaman. Tanaman akan menyerap unsur hara sesuai dengan kebutuhan tanaman sehingga pertumbuhan tanaman akan bergantung dengan ketersediaan unsur hara dalam tanah atau media tanamnya. Apabila unsur hara yang terkandung pada media tanam sedikit maka tanaman akan kekurangan unsur hara dan pertumbuhan akan terhambat, namun apabila unsur hara yang tersedia dalam media tanam tinggi melebihi kebutuhan tanaman maka tanaman hanya menyerap unsur hara yang dibutuhkan saja. Banyaknya jumlah dan luas daun berpengaruh pada banyaknya makanan yang diperoleh tanaman pada proses fotosintesis.

Berdasarkan penelitian Jumlah daun pada akhir penelitian tidak memiliki perbedaan nyata. Namun pada 21 HST menunjukkan bahwa Grand 22 mempunyai kemampuan beradaptasi dengan baik dilingkungan penelitian selain jumlah daun menunjukkan perbedaan juga luas daun yang lebih besar. Hal tersebut sampai pada akhir masa panen menunjukkan Grand 22 mempunyai berbeda nyata pada variabel luas daun. Pertumbuhan yang baik tersebut diharapkan hasilnya juga baik Prawitasari (2003), menjelaskan bahwa perubahan pertumbuhan kearah perkembangan hasil tanaman dipengaruhi oleh kemampuan kerja enzim dalam tubuh tanaman dan faktor lingkungan. Pertumbuhan dan perkembangan organ ditentukan oleh suatu proses yang dinamakan fotosintesis bila hasilnya baik maka akan menghasilkan pertumbuhan dan perkembangan tanaman yang baik pula, hal ini dapat terukur pada penambahan jumlah organ tanaman, perluasan sel-sel dan proses fotosintsis dapat berjalan dengan baik bila faktor (hara, suhu dan udara) yang mempengaruhi proses tersebut berada pada kondisi optimum Willy, 1998. Suhu mempunyai pengaruh kuat pada reaksi-reaksi biokimia dan fisiologi 
P-ISSN $2580-7781$

E-ISSN $2615-3238$

tanaman juga akan menentukan tingkat berbagai aktifitas tanaman, seperti penyerapan unsur hara dan air (Setyati, 1989). Tanaman kubis dapat menyerap unsur hara dengan baik apabila suhu disekitarnya dalam kondisi optimal.

3. Umur Muncul Krop (hari)

Krop kubis yaitu bagian yang di komsumsi pada tanaman kubis yaitu berbentuk bulat, tanaman kubis tersusun dari daun batang dan mengandung banyak air, pada percobaan ini umur muncul krop menunjukan tidak ada beda nyata terhadap semua perlakuan pupuk, di ketahui krop mulai muncul pada minggu ke-8 di mulai dengan penyangkokan bagian daun yang paling atas mulai merunduk atau membentuk setengah lingkaran, dan disusul daun berikutnya yang mengikuti alur membentuk bulatan sampai membentuk krop.

Parameter yang diamati pada hasil pertumbuhan tanaman kubis terdiri atas tinggi tanaman, jumlah daun, umur membentuk krop, dan luas daun. Sedangkan untuk variabel hasil tanaman, yang diamati adalah panjang akar, berat segar tanaman, berat segar krop, diameter krop, diameter batang.

Hasil analisis dari pertumbuhan tanaman kubis dapat dilihat pada tabel dibawah.

Tabel 2. Hasil Analisis Ragam Komponen Hasil Tanaman

\begin{tabular}{llccc}
\hline NO & \multicolumn{1}{c}{ Variabel } & Varietas & Dosis Pupuk & $\begin{array}{c}\text { Interaksi } \\
\text { Varietas dan } \\
\text { dosis pupuk }\end{array}$ \\
\hline 1 & Berat segar krop & $* *$ & tn & tn \\
2 & Berat segar & tn & tn & tn \\
& tanaman & & & tn \\
3 & panjang akar & tn & tn & tn \\
4 & Diameter krop & $* *$ & tn & tn \\
5 & diameter batang & $* *$ & $* *$ & \\
\hline
\end{tabular}

\section{Berat Segar Krop}

Krop merupakan bagian penting bagi tanaman kubis dimana sebagai tolak ukur bagi petani kubis dalam keberhasilan penanaman kubis krop dimana hasil pada tanaman kubis adalah diambil krop untuk di konsumsi krop kubis tersususn dari daun batang lunak dan kandungan air. Berat segar krop merupakan tahap dimana penimbangan hasil krop tanpa akar batang dan daun, dari hasil penelitian 
P-ISSN 2580 - 7781

E-ISSN 2615 - 3238

menunjukkan berat segar krop memiliki perbedaan nyata pada varitas kubis. Varietas sehati menunjukkan berat krop lebih baik dibandingkan dengan sehati. Meskipun pertumbuhan grand 22 lebih baik namun belum menghasilkan berat krop yang optimal. Hal tersebut dapat dipengaruhi jumlah pupuk yang belum optimal sehingga baik grand 22 maupun sehati masih mempunyai potensi hasil yang lebih baik. Pada dasarnya berat segar krop dipengaruhi oleh jumlah daun. Variabel menunjukkan signifikan pertumbuhan Presentase krop merupakan perbandingan antara berat segar krop ( berat daun yang dapat dikonsumsi) dengan berat total tanaman tanpa akar ( berat segar krop ditambah berat total tanaman tanpa akar). Presentase krop bertujuan untuk mengetahui laju transpot cadangan makanan untuk pembentukan krop pada masa generatif sehingga terjadi pengalihan unsur hara yang lebih besar kebagian krop di bandingkan alokasi unsur hara di bagian daun. Pada penelitian kali ini memungkinkan laju transport cadangan makanan belum optimal. Hal tersebut dapat disebabkan karena faktor lingkungan. Pada saat penelitian curah hujan tinggi sehingga memungkinkan tanaman kekurangan cahaya matahari.

2. Berat tanaman segar

Adanya ketersediaan air ini berhubungan dengan berat segar tanaman. Berat segar tanaman merupakan total dari kandungan air didalam tanaman dengan total hasil fotosintesis. Tidak berbeda nyata tersebut dapat dikarenakan semua pupuk yang telah diberikan pada tanaman kubis dapat mencukupi kebutuhan unsur hara yang dibutuhkan oleh tanaman kubis tersebut. Pada dasarnya tanaman akan menyerap unsur hara yang disediakan media tanam sesuai dengan kebutuhannya, sehingga apabila unsur hara yang terkandung pada media tanam tinggi maka unsur hara tersebut tidak diserap tanaman seluruhnya hanya sesuai dengan kebutuhan tanaman

Berat segar tanaman terdiri dari berat segar akar, daun dan batang tanaman. Berat segar daun mengindikasikan kemampuan akar menyerap unsur hara kemudian ditranslokasikan kebagian jaringan daun dalam bentuk penimbunan cadangan makanan. Pada dasarnya tanaman akan menyerap unsur hara yang disediakan media tanam sesuai dengan kebutuhannya, sehingga apabila unsur hara 
P-ISSN $2580-7781$

E-ISSN 2615 - 3238

yang terkandung pada media tanam tinggi maka unsur hara tersebut tidak diserap tanaman seluruhnya hanya sesuai dengan kebutuhan tanaman. Daun merupakan organ tanaman tempat mensintesis makanan untuk kebutuhan tanaman maupun sebagai cadangan makanan. Daun memiliki klorofil yang berperan dalam melakukan fotosintesis. Semakin banyak jumlah daun, maka tempat untuk melakukan proses fotosisntesis lebih banyak dan dan hasilnya lebih banyak juga. Dengan kata lain pada hasil analisis sidik ragam Berat segar daun ini tidak beda nyata namun pada perlakuan NPK menunjukan angka yang lebih tinggi dari pada perlakuan lainya. Berat segar daun dipengaruhi oleh banyaknya unsur hara yang diserap oleh akar kemudian disimpan dalam daun sebagai cadangan makanan (asimilat) sehingga mengakibatkan penambahan berat biomasa daun. Berat biomasa daun dipengaruhi oleh kemampuan akar menyerap unsur hara melalui pembentukan sistem percabangan akar yang aktif. Jika dilihat dari hasil sidik ragam menunjukan bahwa perlakuan NPK menunjukan berat segar daun tertinggi meskipun memiliki panjang akar relatif rendah. Hal ini diduga pada perlakuan NPK panjang akar cenderung membentuk percabangan akar baru sehingga memperluas bidang penyerapan unsur hara.

Unsur nitrogen, fosfor, dan kalium memiliki peran penting masing-masing yang saling berhubungan dalam memacu pertumbuhan dan perkembangan tanaman. Nitrogen berperan penting dalam menunjang pertumbuhan vegetatif, pembentukan klorofil, asam amino, lemak, enzim, dan senyawa lainnya, fosfor berperan penting dalam proses pendewasaan tanaman, merangsang pertumbuhan dan perkembangan akar serta memacu proses pembungaan, sedangkan kalium berperan penting dalam membangun dinding sel, memperkuat jaringan tanaman, mengatur membuka-menutupnya guard cell pada stomata daun, meningkatkan ketahanan tanaman terhadap penyakit serta meningkatkan kekuatan tangkai serta batang tanaman (Firmansyah et al., 2017). Meningkatnya proses metabolisme tanaman akan menyebabkan tanaman lebih banyak membutuhkan unsur hara dan meningkatkan penyerapan air yang dibutuhkan dalam pertumbuhan dan perkembangan tanaman. Berat segar yang dihasilkan dari suatu tanaman dipengaruhi oleh hasil fotosintesis yang terkandung dalam tanaman tersebut 
P-ISSN 2580 - 7781

E-ISSN 2615 - 3238

(Gardner et al., 1991). Selain itu, unsur hara fosfor yang terkandung dalam pupuk NPK juga memiliki peranan penting dalam proses pembungaan tanaman bunga kol. Kelebihan kandungan unsur P (fosfor) dapat mengakibatkan krop menjadi lunak, sedangkan kekurangan unsur $\mathrm{P}$ dapat mengakibatkan pertumbuhan krop terhambat sehingga krop menjadi kecil (Gomies et all., 2012).

\section{Panjang akar}

Akar merupakan organ dari tanaman yang berperan penting dalam penyerapan air dan unsur hara dari tanah atau ke daun yang kemudian akan di fotosintesis dan disebarkan ke seluruh bagian tanaman. Dengan semakin banyak dan panjang akar tanaman maka akan semakin media tanam besar cakupan akar untuk menyerap air dan unsur hara dalam media tanam. Berat segar akar menunjukan banyaknya akar yang dihasilkan oleh tanaman untuk menyerap air dan unsur hara pada media tanam, dengan semakin banyaknya akar pada tanaman maka cakupan tanaman dalam memperoleh air dan unsur hara pada media tanam akan semakin tinggi. Berdasarkan tabel annova panjang akar tidak berbeda nyata. Memungkinkan tiap varietas yang diuji pada penelitian kali ini mempunyai kemampuan sama dalam penyerapan hara sehingga pertumbuhan akar hampir sama.

\section{Diameter krop}

Diameter krop sangat erat hubungannya dengan tinggi tanaman dan jumlah daun, semakin banyak jumlah daun, maka diameter krop akan semakin lebar. Selain itu pemanfaatan pupuk sangat berpengaruh menyumbangkan unsur unsur yang berfungsi untuk pertumbuhan dan pembesaran krop pada tanaman kubis (Prawiranata et al. 1991). Berdasarkan penelitian diameter krop berbeda nyata pada varietas tanaman. Berdasarkan rerata dan uji BNT menunjukkan V2 mempunyai diameter krop yang lebih besar daripada V2. Menurut Zulkarnaen et al. (2015), varietas merupakan sekumpulan individu yang dapat dibedakan setiap sifatnya, salah satunya dari segi morfologi. Perbedaan morfologi dari tiap varietas dipengaruhi oleh faktor gentekik dan lingkungan areal pertanaman. 
P-ISSN $2580-7781$

E-ISSN $2615-3238$

\section{Diameter batang}

Berdasarkan tabel Annova diameter tanaman menunjukkan perbedaan sangat nyata pada perlakuan varietas dan pupuk. Perlakuan Varietas menunjukkan V2 mempunyai batang yang lebih besar dibandingkan dengan V2. Berdasarkan uji BNT P2 menunjukkan Pertumbuhan batang yang lebih baik dibanding dengan perlakuan yang lain. Dachlan et al (2013), menyatakan bahwa adanya perbedaan penampilan (fenotipe) dipengaruhi oleh gen dari tanaman itu sendiri serta lingkungan seperti suhu, tanah, kelembaban, dan lain-lain. Gen-gen yang beragam dari masing-masing varietas akan tervisualisasikan dalam karakter yang berbeda juga. Lingkungan akan memberikan peranan terhadap penampakan karakter yang terdapat dalam gen tersebut sehingga didapatkan tanaman sejenis namun memiliki karakter yang berbeda, salah satunya dapat dilihat pada bagian batang tanaman.

\section{KESIMPULAN}

Hasil penelitian menunjukkan V2 yaitu Grand 22 mempunyai adaptasi yang lebih baik di daerah Surotrunan Kebumen. Pupuk rekomendasi P3 yaitu (150 $\mathrm{kg} / \mathrm{ha}$ Urea,200 kg/ha SP36, $150 \mathrm{~kg} / \mathrm{ha} \mathrm{KCL}$ ). Masih memungkinkan dilakukan penelitian lanjutan dengan dosis yang lebih tinggi untuk meningkatkan hasil.

\section{DAFTAR PUSTAKA}

Dachlan, A., N. Kasim dan A. K. Sari. 2013. Uji Ketahanan Salinitas Beberapa Varietas Jagung (Zea mays L.) dengan Menggunakan Agen Seleksi NaCl. Ilmiah Biologi, 1(1): 9-17.

Firmansyah, I., M. Syakir dan L. Lukman. 2017. Pengaruh Kombinasi Dosis Pupuk N, P, dan K Terhadap Pertumbuhan dan Hasil Tanaman Terung (Solanum melonngena L.). Hortikultura, 27(1): 69-78.

Gardner, F. P., R. B. Pearce and R. L. Mitchell. 1991. Phsyology of Crop Plants (Fisiologi Tanaman Budidaya, alih bahasa oleh Herawati Susiolo). Jakarta. University of Indonesia.

Gomies, L., H. Rehatta dan J. Nandissa. 2012. Pengaruh Pupuk Organik Cair RI1 Terhadap Pertumbuhan dan Produksi Tanaman Kubis Bunga (Brassica oleracea var. botrytis L.). Agrologia, 1(1): 13-30.

Prawiranata. W, S. Haran, T. . 1991. Fisiologi Tumbuhan jilid III. Bandung. Institut Teknologi Bandung. 343 hal.

Setiyati. 1989. Dasar-dasar Hortikultura. Institut Pertanian Bogor Press.

Sinclair, Thomas R. (1999). "Batas Hasil Tanaman" . Tumbuhan dan Populasi: apakah ada waktu? . Seminar. Washington DC: Akademi Ilmu Pengetahuan Nasional. 
P-ISSN 2580 - 7781

E-ISSN $2615-3238$

doi : $\underline{10.17226 / 9619}$. ISBN 978-0-309-06427-9 . Diarsipkan dari versi asli

Waugh, D.L., R.B. Cate, L.A. Nelson. 1973. Discontinuous model for rapid correlation, interpretation, and utilization of soil analysis and fertilizer response data. Technical Buletin 7. North Carolina State University Agricultural Experiment Station. 